DOI: 10.2478/ijme-2014-0025

\author{
Ewa Sońta-Drączkowska \\ World Economy Institute \\ Warsaw School of Economics
}

\title{
Fostering innovation and competitiveness in the EU at national and regional level: Report from the conference
}

This year's conference took place on $6^{\text {th }}$ and $7^{\text {th }}$ June 2013 at the Warsaw School of Economics. It was organized by the World Economy Institute. The keynote speech of the first conference day was given by Slavo Radosevic from the School of Slavonic and East European Studies at the University College London, who discussed the innovation policy in Central and Eastern Europe (CEE). This presentation explored the extent to which current innovation policies in CEE economies can be considered conducive to their industrial and technology upgrading. CEE was presented in the context of the taxonomy of EU-27 innovation policies. Afterwards, the key features of ongoing upgrading processes in the CEE countries were highlighted. Based on the presented information, it was argued that the current successes as well as policy inadequacies are largely due to mismatches between reality of upgrading processes and orientation of innovation policies. Finally major arguments on the example of science-industry linkages were illustrated.

The key topic of the first day agenda was the presentation of the statutory research project published in its newest edition titled Poland: Competitiveness Report. This assessment of Poland's competitive position in the European Union has been carried out by the Institute's research team for more than twenty years. This year's edition of the Report seeks to evaluate changes in the competitiveness of the Polish economy in 2012, both at the macroeconomic and regional levels. This assessment was the basis for a further indepth analysis of factors influencing the competitive position of Poland and its regions in years between 2005 and 2012.

A wide range of quantitative and qualitative measures were used to compare the Polish economy with other European Union economies, in particular with those in Central and Eastern Europe (EU-10). The planes of comparison included gross domestic product (GDP) growth, GDP per capita, income inequality and the poverty levels, as well as the growth and structure of foreign trade, revealed comparative advantages in trade and their changes over the time, the size and growth of foreign direct investment, and the balance of payments. On the basis of these analyses, forecasts have been presented for 
changes in the competitiveness of the Polish economy in the oncoming years. Moreover, priorities have been indicated for pro-competitive economic policies.

The second session of the first day was devoted to the topics related to the comparison of different countries' experience in the area of innovation, performance and policies. Speakers presented examples from Northwest England, Hungary, Czech Republic, Russia and Romania. Professor Martin Lynn, Director of Enterprise at MMU School of Business and Law, presented how universities in Northwest England are engaging in the process to support further innovations and to encourage business creation and business growth. The research paper authored by Laszlo Csonka, Research Fellow at IKU Innovation Research Centre, concentrated on the main internationalization patterns of Hungarian SMEs in a high tech (IT) and a traditional (engineering services) industries related to their research, development and innovation (RDI) activities. Anna Kaderabkova from the Centre for Innovation Studies, University of Economics and Management, in the Czech Republic presented the outcomes of her research, commissioned by Technology Agency of the Czech Republic (government body for applied research) concerning factors and outcomes of large-scale programs supporting development of science-industry linkages between key knowledge and innovation actors in the country. Marina Fedotova and Igor Lukasevich from the Financial University under Government of Russian Federation presented the results of the innovation potential analyses of various Russian regions. Finally, Horatiu Dragomirescu from Bucharest University of Economic Studies in Romania, presented innovation paradoxes and, based on examples drawn from the recent literature, discussed boldest facets of its phenomenological complexity that challenges the conventional wisdom of innovation management.

Sessions held on $7^{\text {th }}$ June was focused on government policies as well as other forms of support that foster innovation and competitiveness at national and regional levels. The keynote speaker for the second conference day was Ken Guy, the head of Science and Policy Division at the OECD. He shared the key issues regarding science, technology and innovation policy seen from the OECD perspective.

The key agenda topic of the first session on the second conference day was panel discussion on the project "Stimulating Learning for Idea-to-Market (SLIM)". This project was coordinated by the Manchester Metropolitan University (the United Kingdom) with Project Partners: World Economy Research Institute in the Warsaw School of Economics (Poland), the University of Rijeka, and the Faculty of Economics and Business, University of Zagreb (both from Croatia) and EFMD (Belgium) and Associate Partners: BTM Mazovsze Ltd. (Poland), The Federation of Small Businesses (the United Kingdom), as well as Science and Technology Park of the University of Rijeka, and Arenda (both from Croatia). The rationale for panel discussion on this project was to focus on fostering entrepreneurship as a condition for economic development in a knowledge-based economy. Several studies underlined the gap between the supply and demand of knowledge, both in 
quantity and relevance, often resulting in a deficit of business skills and competences. This challenge is taken on by the SLIM project, which has been developed to bridge this gap.

During the session, the most important characteristics of SLIM project were presented. In particular, two key elements of it: The first one was an online self-assessment management tool, created by the Manchester Metropolitan University Business School. The tool enables SMEs to gain an instant snapshot of their business proposal and identify which areas require increased focus. The second component consists of the results of an innovative program on Intellectual Property Management developed by the World Economy Research Institute at the Warsaw School of Economics. The main challenge of innovation transfer in the framework of SLIM project was to adapt these two elements and in order to make them accessible to SMEs. Questions discussed during the session focused on the most efficient forms of commercialization of ideas, key needs of firms in the context of innovative activity, the most useful methods of teaching entrepreneurs on commercialization of their ideas and the role of government support for commercialization of knowledge and implementing innovations.

In the second session of the second conference day the speakers discussed their research outcomes on pro-innovative and pro-competitive policies implemented by governments to boost innovation and competitiveness. Bendreff Desilus from the Universidad La Salle de México confronts two perspectives on the role of government in supporting competitiveness. The first relates to the contribution of M. Porter who argues that nations choose whether or not to be successful as prosperity is no longer subject to factors inherent to the nations. The second one perspective presented by Robert Gilpin, shares the ideas of P. Krugman and believes that new economic theories and their implications will lead to the conclusions that governments and their policies are, and will be, important for the proper functioning of the international economy. Tomasz Napiórkowski from the Warsaw School of Economics compared the US National Innovation System with the one in China and selected European countries, proving that well-developed NISs are keystones in the process of commercialization of R\&D results that lead to an increased efficiency of such initiatives. Paweł Pietrasiński, Warsaw School of Economics and Minister Counselor, Trade and Investment Section Embassy of The Republic of Poland in the USA, analyzed how to effectively build a governmental "bridge organization", linking young Polish companies with the innovative Silicon Valley's ecosystem, as well as how to design the advanced support programs for the competitively selected enterprises, based on a multi-phases approach, starting from the "technology boot-camp" in Poland and finishing with its business acceleration stage on the US market. The final contribution of the second session was delivered by David López-Sanchez, Antonio Mihi-Ramírez, Katarzyna Dziuda from the University of Granada in Spain. The presenters concentrated on the use of macroeconomics policies that cause changes in economic cycles with the aim of examining if the application of policies to stimulate an economy helps reduce hardness and duration of a recession. 
At the last session of the conference innovation and competitiveness from the regional and sectoral perspectives were discussed. Christopher Kummer, Director of Graduate Business Programs at Webster University in Vienna, presented his paper "The Impact of Competitiveness on Mergers \& Acquisitions", in which his research questions concentrated on the extent how M\&A is influenced by competitiveness factors. Matthias Mrożewski from the Berlin Institute of Technology presented research on "The Determinants of Entrepreneurship across Regions in Europe." Based on the findings that there is little empirical literature investigating the actual determinants of entrepreneurship on a cross-regional level, he provided empirical evidence on the determinants of entrepreneurship in Europe. By leveraging Eurostat data on core European cities, the researcher has shown that the regional demographic structure, the unemployment rate, the education level as well as social ties in the region play a major role in explaining entrepreneurial activity in Europe. The second conference day was closed by presentation of two researchers from the Poznań University of Economics. Dorota Czyżewska discussed "The Empirical Evidence and First Assessment of the Competitiveness Clusters Policy in France" and Marlena Dzikowska provided results of her study on "The Value Chain Module Relocations and the Competitive Position of a Relocating Company." Her study focused on the perspective of Polish companies from the clothing and automotive industries.

This year's conference was an excellent occasion for the presentation of the current status of the newest international research papers in the area of innovation and competitiveness, as well as formulation of practical implications for development of regional and national policies to foster innovativeness and innovations dissemination. Additionally, it created an opportunity for networking among international researchers who focus their activities around topics related to innovation. 